ISSN 1991-8631

Original Paper

http://indexmedicus.afro.who.int

\title{
Pesticide residues in fish from the Densu River Basin in Ghana
}

\author{
J.R. FIANKO ${ }^{1,4 *}$, A. DONKOR ${ }^{2}$, S.T. LOWOR ${ }^{3}$ and P.O. YEBOAH ${ }^{4}$ \\ ${ }^{I}$ Department of Chemistry, NNRI/GAEC, P.O. Box LG 80, Legon, Accra, Ghana. \\ ${ }^{2}$ Department of Chemistry, University of Ghana, Legon, Accra. \\ ${ }^{3}$ Cocoa Research Institute of Ghana, Akim Tafo. \\ ${ }^{4}$ School of Nuclear and Allied Sciences, University of Ghana, Legon, Accra. \\ *Corresponding author, E-mail: jrfianko@yahoo.com
}

\begin{abstract}
The Densu River is a typical river flowing through agricultural areas in Southern Ghana. Six fish species from different locations in the river were sampled and analyzed for residues of pesticides and metabolites using GC with ECD/FID. The results of the study indicate that all the detected residues and metabolites in fish samples from the Densu River Basin were organochlorines (OCs). Among the pesticides residues analyzed, DDE, $\alpha$-endosulfan, $\gamma-\mathrm{HCH}, \delta-\mathrm{HCH}$, heptachlor and endosulfan sulphate, were predominant in all the samples. About $50 \%$ of the samples recorded positive detection of DDE while $\alpha$ endosulfan was detected in $60 \%$ of the samples. $\gamma-\mathrm{HCH}, \delta-\mathrm{HCH}$ were detected in $75 \%$ and $65 \%$ of the samples respectively with heptachlor occurring in $80 \%$ of the samples. In almost all the fish species analyzed, DDE was the predominant compound having a mean value of $7.99 \mu \mathrm{gKg}^{-1}$. Higher concentrations of pesticide residues were detected in fish samples from the Densu River at Nsawam than the other locations. The total concentration of residues in the fish samples ranged between $0.49 \mu \mathrm{gKg}^{-1}$ and $8.90 \mu \mathrm{gKg}^{-1}$ with the highest level detected in Hepsetue odoe $(H O-N)$. The sequence of pesticide residues detected in fish samples were HO-N > HN-N > CO-N > CG-N > TZ-N > CN-W > TZ-W > CG-W. The high ratio of DDE/DDT in fish samples $(0.1-6.9$ with a mean of 2.51) indicated probably old input of DDT and significant degradation. The $\gamma$ - $\mathrm{HCH}$ isomer (lindane) was the dominant $\mathrm{HCH}$ in fish samples suggesting a preferential usage of lindane (purified $\gamma-\mathrm{HCH}$ ) in these areas. The $\delta-\mathrm{HCH} / \gamma-\mathrm{HCH}$ ratios in most fish samples were low indicating the present input of the pesticide lindane from non-point sources.
\end{abstract}

(C) 2013 International Formulae Group. All rights reserved.

Keywords: Pesticide residues, Fish, Densu River Basin, Ghana, exposure

\section{INTRODUCTION}

The Densu River Basin contributes significantly to the overall agricultural production of Ghana. Ghana's vast water resources especially the Densu River and its tributaries are among those most affected by environmental stress imposed by human population growth, anthropogenic activities, agriculture, industrialization, improper disposal and management of waste (WRC, 2007). The use of pesticides to control pests has been in practice in Ghana for over several decades (Ntow, 2005). Despite the benefits of chemistry for agriculture production and public health, the increased higher application 
of pesticides has resulted in food contamination.

Pesticides gained notoriety for their high toxicity, persistence and bioaccumulative ability in food chains (Tanabe and Kawata, 2009; Liu et al., 2002). Contamination of food results in exposure to toxic pesticide residues for the resident populations leading to harmful health effects. Ingestion of pesticide in food has been linked with health conditions that are a major source of morbidity and mortality and increased risk of skin, bladder and lung cancer at very low concentrations (Jiries et al., 2002; Tariq et al., 2007). Pesticides in fish are extremely important because of their potential impact on human health and the aquatic ecosystems. At low concentrations, the combined effect of persistent synthetic pesticides causes suppression of immune response and hypersensitivity to chemical agents. Causes of breast cancer, reduced sperm count, male sterility and death are well documented as a result of pesticide ingestion (Carvalho, 2006).

Studies in Ghana indicated the presence of pesticide residues in vegetables, fruits and fish, at locations known for pesticide usage (Ntow, 2005; Amoah et al., 2006; Mensah et al., 2004; Aboagye, 2002). Growth in agrobased industries, increase in agriculture activities, improper storage and lack of sound disposal facilities have caused contamination of soil and water bodies resulting in a rapid increase in the number of pesticides into the Aquatic ecosystem (FAO/WHO, 2007). The Densu River basin is located in a highly intensive agriculture area where large quantities of pesticides are used. The Densu basin is one of the many basins in the country that has shown a propensity towards development of previously rural areas into urban communities. The basin is primarily agricultural although the growth of relatively large cities and urbanization of rural lands have made the area susceptible to pesticide contamination from untreated domestic, municipal and agro-industrial waste.

The Densu River basin constitutes one of Ghana's most productive agro-ecological ecotones (Attua, 2003), the cradle of Ghana's agricultural active zone. The modernization of agricultural practices in the country has led to an increase use of pesticides some of which are known to be highly persistent and toxic to non - target organisms. Economic activities in the basin also include fishing and industrial development. Human exposure to pesticides through fish and fish products from the Densu River Basin may be excessive, especially through ground application of pesticides in agricultural activities and the control of vector-borne diseases for public health. Fish from the basin serves as the major source of income for most of the inhabitants and constitutes an important source of protein in Ghana.

The presence of pesticide residues in fish and fish products may affect human health and create barriers to trade in agricultural commodities. Bioaccumulation and bio-concentration of pesticides in fish species are capable of reaching toxic levels even when exposure is low. Consumption of contaminated fish and fisheries products could therefore pose a serious risk to human (Carvalho, 2006). Excessive usage can have effects such as disruption of neurological cellular functions, acute and chronic neurotoxicity, tissue or organ damage, irritation and chemical burns. This study therefore seeks to assess the types and levels of pesticide residues in fish samples from the Densu River Basin, the extent of spatial distribution of pesticide residues and establish the extent of pesticide pollution of the Densu River.

\section{MATERIALS AND METHODS}

The study area

The Densu River Basin covers approximately 2,565 $\mathrm{km}^{2}$ and lies between 
latitude $5^{\circ} 30^{\prime} \mathrm{N}-6^{\circ} 20^{\prime} \mathrm{N}$ and longitude $0^{\circ}$ $10^{\prime} \mathrm{W}-0^{\circ} 35^{\prime} \mathrm{W}$ (Figure 1). The basin is predominantly underlain by Precambrian granitoids comprising mostly Cape Coast granite and granodiorites with associated gneisses. The study area is a low lying plain with forest plateau and generally undulating with scattered steep hills and largely covered with deciduous forests. The Densu Basin has two different climatic zones (wet semiequatorial and dry equatorial climate zones). The wet semi-equatorial climatic zone occurs in the north where the annual rainfall is approximately $1,700 \mathrm{~mm}$. The coastal area experiences the dry equatorial climate where the annual rainfall is approximately $800 \mathrm{~mm}$. Both climatic zones, however, experience homogeneous temperatures in the range 23 $32{ }^{\circ} \mathrm{C}$ with mean annual value of $27^{\circ} \mathrm{C}$ (WRI, 2003).

\section{Sampling}

Six fish species (Heterotis niloticus, Channa obscura, Hepsetus odoe, Tilapia zilli, Clarias gariepinus and Chrysichthys nigrodigitatus) (Table 1) from the basin were selected for the study due to differences in their feeding habits. The fish samples were bought when still alive directly from the fishermen. Sampling was done bi-monthly over a period of one year from January to December, 2009 The samples were immediately wrapped in aluminum foil, appropriately labeled, transported to the laboratory on ice and kept at $-20{ }^{\circ} \mathrm{C}$ in a freezer prior to extraction.

\section{Sample extraction}

The extraction of pesticide residues from the fish samples was performed by solid dispersion method as described by the U.S. Food and Drug Administration, (FDA, 1994) and Akerblom (1995). Two hundred grams fish samples (fresh weight) of each fish species were homogenized separately in a stainless steel blender. About $25 \mathrm{~g}$ of the homogenized fish samples of each species were grounded separately with $35 \mathrm{~g}$ of $\mathrm{Na}_{2} \mathrm{SO}_{4}$ (anhydrous) in a mortar to a freeflowing powder. The powder was extracted in a flask by shaking successively with ethyl acetate $(50.3 \times 20 \mathrm{ml})$. The combined extract was filtered through a cotton wool and the solvent evaporated at $40{ }^{\circ} \mathrm{C}$ with rotary evaporator to near dryness. The concentrate was recovered with $(3 \times 1.5 \mathrm{ml})$ portions of cyclohexane. The organic phase was then subjected to clean-up.

\section{Clean-up of sample extracts}

Conditioned 8-ml C-18 solid phase extraction (SPE) cartridges were used for the sample clean-up (Zhou et al., 2000). The SPE cartridge system was conditioned by washing with $5 \mathrm{ml}$ distilled water, $5 \mathrm{ml}$ ethyl acetate followed by $5 \mathrm{ml}$ methanol. Each fish extract was percolated through the cartridges with a flow rate of approximately $5 \mathrm{ml} / \mathrm{min}$ under vacuum pump. The pesticides trapped in the cartridges were eluted with $6 \mathrm{ml}(2 \times 3 \mathrm{ml})$ ethyl acetate. The sample extract was concentrated using the rotary evaporator aided with a water chiller to $2 \mathrm{ml}$ for GC analysis.

\section{Analysis and quantification of pesticides}

Fish samples were analyzed in a gas chromatograph (Varian CP- 3800 gas chromatograph) equipped with Ni-63 electron capture detector (ECD) and Flame ionization detector (FID). Extracts of samples were interspersed with analytical standards of interest, placed on auto-sampler with standards at the start, between every 15 samples and the last of the GC sample run. The pesticide residue components were identified by comparing their retention times with those of the standard mixture of the pesticides. Quantification was based on comparison with calibration curves in the concentration range of 0 to $200 \mu \mathrm{g} / \mathrm{L}$. The gas chromatograph's conditions were as follows: injector temperature, $225{ }^{\circ} \mathrm{C}$; injector mode, 
splitless; oven temperature, programmed from $70{ }^{\circ} \mathrm{C}$, held for $2 \min$ to $180{ }^{\circ} \mathrm{C}$ at a rate of 25 ${ }^{\circ} \mathrm{C} / \mathrm{min}$, then from $180{ }^{\circ} \mathrm{C}$ to $290{ }^{\circ} \mathrm{C}$ at a rate of $10{ }^{\circ} \mathrm{C} / \mathrm{min}$, electron capture detector temperature $300{ }^{\circ} \mathrm{C}$, injector volume $1.0 \mu \mathrm{L}$. The flame ionization detector working conditions were oven temperature, $60{ }^{\circ} \mathrm{C}$ held for $2 \mathrm{~min}$ to $180{ }^{\circ} \mathrm{C}$ at a rate of $35{ }^{\circ} \mathrm{C} / \mathrm{min}$, then increased to $270{ }^{\circ} \mathrm{C}$ at a rate of $2{ }^{\circ} \mathrm{C} / \mathrm{min}$, and finally increased to $300{ }^{\circ} \mathrm{C}$ at a rate of $5^{0} \mathrm{C} / \mathrm{min}$ and held for 10 minutes, the detector temperature was $310{ }^{\circ} \mathrm{C}$. The injector mode was splitless and the injection volume $2 \mu \mathrm{L}$ (Zhou et al., 2000).

\section{Control/quality assurance}

Quality control and quality assurance as prescribed by the CODEX Alimentarus Committee were incorporated in the analytical scheme. Quality assurance measures applied in the laboratory included rigorous contamination control procedures (strict washing and cleaning procedures), monitoring of blank levels of solvents, equipment and other materials, analysis of procedural blanks, recovery of spiked standards, monitoring of detector response and linearity. During extraction, blanks and duplicates were included in the analysis and re-calibration standards run frequently to check the integrity of the calibration curve. Aliquot $(100 \mathrm{ml})$ of each solvent was concentrated to $2 \mathrm{ml}$ and analyzed to check the contamination from the reagents (FAO/WHO, 2007). Percentage recoveries in spiked samples were between $68.5-102 \%$ hence the results of the study were not corrected for recoveries since all were within the normal acceptable range of 65-120\% (Hill, 2000; FAO/WHO, 2007).

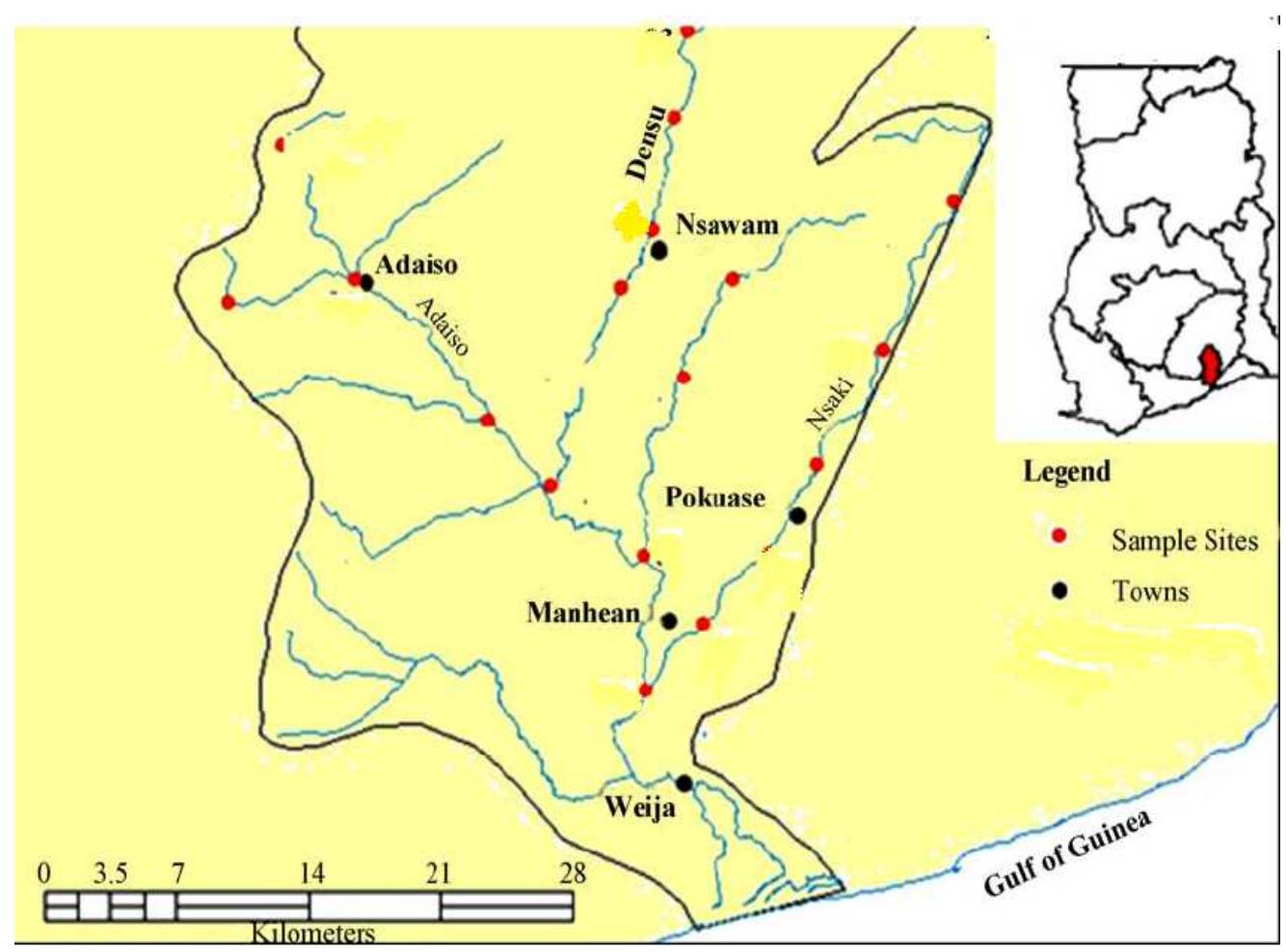

Figure 1: Map of study area showing sampling sites. 
Table 1: Characteristics of Fish species sampled from the Densu River Basin.

\begin{tabular}{lccc}
\hline Species & Feeding habit & common Name & Code \\
\hline Heterotis niloticus & carnivorous & African arowana & HN-N \\
Channa obscura & carnivorous & Snake head & CO-N \\
Hepsetus odoe & carnivorous & African pike & HO-N \\
Tilapia zilli -1 & herbivorous & Tilapia & TZ-N \\
Clarias gariepinus & carnivorous & Mud fish & CG-N \\
Clarias gariepinus 1 & carnivorous & Mud fish & CG-W \\
Chrysichthys nigrodigitatus & carnivorous & Catfish & CN-W \\
Tilapia zilli-2 & herbivorous & Tilapia & TZ-W \\
\hline
\end{tabular}

\section{RESULTS AND DISCUSSION}

The percentage positive detection, minimum and maximum concentrations of pesticide residues detected in fish samples are summarised in Table 2. The residues of $\gamma$ $\mathrm{HCH}, \quad \delta-\mathrm{HCH}$, heptachlor, aldrin, $\gamma-$ chlordane, $\alpha$-endosulfan, endosulfan sulphate, p'p'-DDE, dieldrin, endrin, p'p'-DDT, endrin aldehyde, endrin ketone and methoxychlor were detected in all fish species sampled with varying concentrations among species and locations. The detected residues reflected the type of pesticides that have been used in the respective areas. In Ghana the organochlorine pesticides were extensively used in the past in cocoa, oil palm, citrus and pineapple plantations as well as the control of vector borne diseases in public health (MOFA, 2003). DDT and dieldrin have been used in public health and agriculture, while dieldrin and aldrin have been used against termites. Runoff from applied areas are likely to be drained into rivers and then taken up by biota.

Among the pesticides residues detected, levels of DDE, $\alpha$-endosulfan, $\gamma$ $\mathrm{HCH}, \delta-\mathrm{HCH}$, heptachlor and endosulfan sulphate, were predominant in all the samples (Table 2). About $50 \%$ of the samples recorded positive detection of DDE while $\alpha$-endosulfan was detected in $60 \%$ of the samples. Heptachlor was detected in $80 \%$ of fish samples while $\gamma-\mathrm{HCH}, \delta$ - $\mathrm{HCH}$ were detected in $75 \%$ and $65 \%$ of the samples respectively (Figure 2).
The total mean concentration of pesticide residues in the fish species ranged from $0.49 \mu \mathrm{gKg}^{-1}$ to $8.90 \mu \mathrm{gKg}^{-1}$ with the highest level detected in Hepsetue odoe (HO$N)$ (Table 3). Heteriotis noloticus (HN-N) and Channa obscura (CO-N) contained relatively higher concentrations of pesticide residues which were $7.78 \mu \mathrm{gKg}^{-1}$ and $4.89 \mu \mathrm{gKg}^{-1}$ respectively. Concentrations were lower in the herbivorous species than in the carnivorous species which are benthic in nature. Pesticides being lipophilic reside and accumulate in fatty tissues, gain entrance to the carnivores by ingestion and bioaccumulate. The sequence of pesticide residues detected in fish samples was HO-N > $\mathrm{HN}-\mathrm{N}>\mathrm{CO}-\mathrm{N}>\mathrm{CG}-\mathrm{N}>\mathrm{TZ}-\mathrm{N}>\mathrm{CN}-\mathrm{W}>$ TZ-W > CG-W. The variation in concentration of pesticides detected in fish species could be attributed to differences in feeding habits and metabolic characteristics of the fish species. The herbivorous diet is dominated by phytoplanktons or benthic algae while the carnivorous feeds on insects, detritus and other herbivores.

Location and feeding habit had significant effect on the amount of residues present in the fish. As pesticides enter the aquatic ecosystem in pulses and are rapidly adsorbed, degraded, and metabolized water concentrations do not accurately reflect the actual exposure of fish to these pesticides. The organochlorine pesticides DDT, $\gamma-\mathrm{HCH}, \delta$ $\mathrm{HCH}$, heptachlor, $\alpha$-endosulfan and endosulfan sulphate were the predominant 
compounds in fish species from suburban and agricultural based areas (Nsawam and Weija). In almost all the fish species analyzed, DDE was the predominant compound (Figure 3), having a mean of $7.99 \mu \mathrm{gKg}^{-1}$. Higher concentrations of pesticide residues were detected in fish samples collected from the Densu River at Nsawam. This may be partly due to a combination past and present usage of these pesticides in both agricultural activities and public health programs in the catchment areas.

Residue levels in fish vary with species due to differences in biology (trophic level, habitat and reproductive season), exposure, detoxification capability, and ecology (Wasswa and Kiremire, 2004). Geographical variation indicates that pesticide residue concentrations were significantly higher at the Nsawam end of the basin as compared to other places in the study area. The differences in residue levels may also be a reflection of different exposure regimes and innate individual differences in metabolism. The variation in concentrations of residues in different fish species suggested a higher accumulation potential by those species. The diet and metabolic characteristics of the fish species affect the accumulation of pesticides in fish. Tilapia is primarily a herbivorous cichlidae, its diet is dominated by phytoplankton (chlrophyllcea, cyanophycea and englenophycea) or benthic algae. The catfish represent the most common species in the aquatic ecosystem and feeds on insects (chiromidae) and detritus (Adeyemi et al., 2008)

Comparing similar fish species (Tilapia Zilli and Clarias gariepinus) from two different locations with appreciable levels of residues, samples from Nsawam (TZ-N and CG-N) recorded elevated levels of the pesticide contaminants than those from Weija (TZ-W and CG-W) (Figure 4). The mean values registered were $1.53 \mu \mathrm{gKg}^{-1}$ and 1.80 $\mu \mathrm{gKg}^{-1}$ for Tilapia zilli (TZ-N) and Clarias gariepinus (CG-N) respectively from Nsawam area while the Weija area had $0.49 \mu \mathrm{gKg}^{-1}$ in both Tilapia zilli (TZ-W) and Clarias gariepinus (CG-W).

Table 2: Reference dose (RfD), pesticide and metabolite concentrations (fresh weight basis) in fish samples from the Densu River Basin.

\begin{tabular}{lcccc}
\hline Substance & $\begin{array}{c}\text { Reference dose } \\
\left(\boldsymbol{\mu g k g}^{-1} \mathbf{d a y}^{-1}\right)\end{array}$ & \multicolumn{3}{c}{$\begin{array}{c}\text { Concentration } \\
\left(\mathbf{\mu g k g}^{-1}\right)\end{array}$} \\
\cline { 2 - 5 } & & min & max & mean \\
\hline$\gamma$ - HCH & 0.30 & 0.10 & 17.65 & 4.94 \\
$\delta$ - HCH & 3.00 & 0.20 & 17.60 & 3.12 \\
heptachlor & 0.10 & 1.30 & 21.50 & 5.49 \\
aldrin & 0.10 & 0.10 & 2.90 & 0.65 \\
$\gamma$-chlordane & 0.50 & 0.25 & 10.15 & 3.02 \\
$\alpha$-endosulfan & 0.05 & 0.15 & 16.50 & 3.56 \\
p'p'-DDE & 0.50 & 0.10 & 30.90 & 7.99 \\
dieldrin & 0.10 & 0.15 & 9.90 & 3.01 \\
endrin & 0.20 & 0.10 & 6.95 & 2.19 \\
p'p'-DDT & 0.50 & 0.10 & 12.50 & 4.01 \\
endrin aldehyde & 0.20 & 0.10 & 1.55 & 0.51 \\
endosulfan Sulphate & 0.05 & 0.10 & 10.85 & 3.80 \\
endrin ketone & 0.20 & 0.10 & 6.70 & 2.59 \\
methoxychlor & 5.00 & 0.10 & 12.60 & 2.27 \\
\hline
\end{tabular}


Table 3: Levels of pesticide residues in pooled whole body homogenized fish species from the Densu River basin $\left(\mu \mathrm{gKg}^{-1}\right.$ fresh weight basis).

\begin{tabular}{lcccccccc}
\hline Compound & CG-W & CN-W & TZ-W & HN-N & CO-N & HO-N & TZ-N & CG-N \\
\hline$\gamma$-HCH & 1.95 & 1.95 & 0.1 & 13.6 & 0.35 & 17.65 & 0.9 & 3.0 \\
- HCH & 0.45 & 0.85 & 0.2 & 0.35 & 17.6 & 4.25 & 0.85 & 0.4 \\
heptachlor & 1.3 & 3.1 & 1.5 & 9.0 & 3.5 & 21.5 & 2.4 & 1.6 \\
aldrin & 0.4 & 0.45 & 0.1 & 0.55 & 0.15 & 2.9 & 0.15 & 0.5 \\
$\gamma$-chlordane & 0.25 & 0.35 & 0.8 & 7.25 & 0.8 & 10.15 & 4.2 & 0.35 \\
a-endosulfan & 0.15 & 3.1 & 0.75 & 16.5 & 0.63 & 2.3 & 0.7 & 4.35 \\
p'p'-DDE & 0.65 & 0.6 & 0.1 & 9.9 & 30.9 & 17.3 & 0.6 & 3.9 \\
dieldrin & 0.15 & 1.25 & 0.2 & 9.9 & 0.75 & 9.3 & 0.25 & 2.25 \\
endrin & 0.25 & 0.2 & 0.1 & 5.15 & 2.1 & 6.95 & 2.65 & 0.15 \\
p'p'-DDT & 0.3 & 0.1 & 1.0 & 10.8 & 4.45 & 12.5 & 0.75 & 2.2 \\
endrin & & & & & & & & \\
aldehhde & 0.1 & 0.75 & 0.1 & 1.55 & 0.15 & 0.65 & 0.35 & 0.45 \\
endosulfan & & & & & & & & \\
Sulphate & 0.1 & 0.1 & 0.1 & 9.05 & 4.25 & 10.85 & 4.75 & 1.2 \\
endrin ketone & 0.1 & 2.05 & 0.9 & 2.7 & 1.95 & 6.7 & 2.6 & 3.7 \\
methoxychlor & 0.7 & 0.1 & 0.95 & 12.6 & 0.85 & 1.65 & 0.2 & 1.1 \\
\hline
\end{tabular}

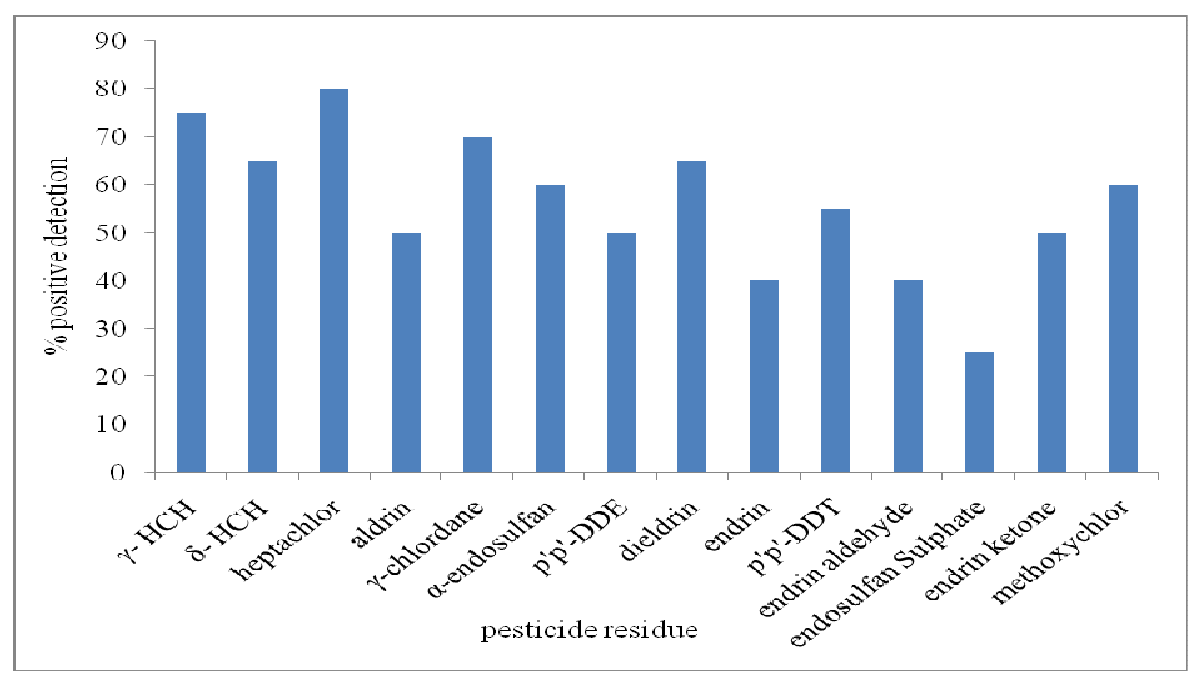

Figure 2: Percentage positive detection of pesticide residues in fish samples. 


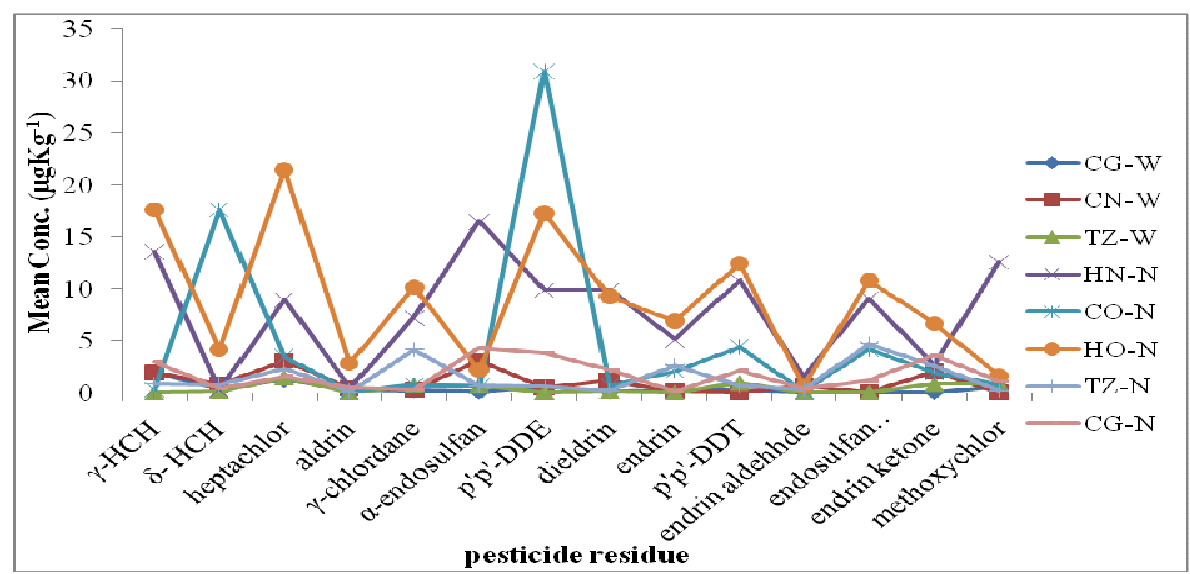

Figure 3: Pesticide residue in fish species from the Densu River Basin.

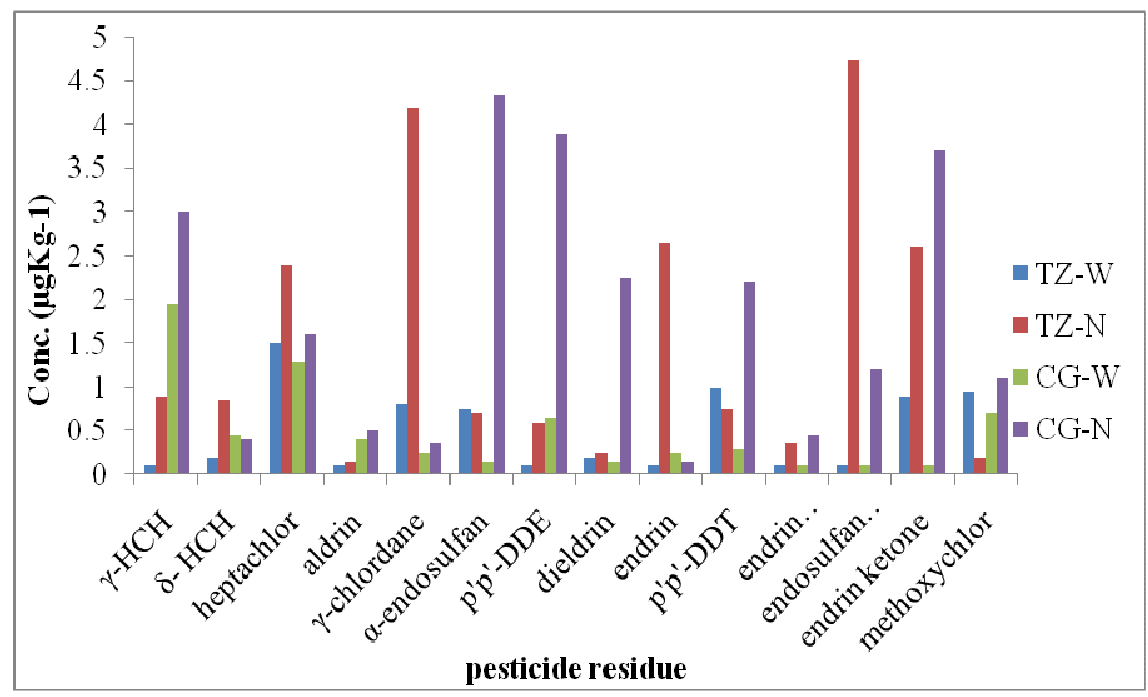

Figure 4: Variation of pesticide residues in fish species among sampling locations.

Contamination pattern of OCs in fish samples was generally in the order of p'p'-DDE > heptachlor $>\gamma-\mathrm{HCH}>\mathrm{p}^{\prime} \mathrm{p}^{\prime}$-DDT $>$ endosulfan Sulphate $>\alpha$-endosulfan $>\delta$ - $\mathrm{HCH}>\gamma$ chlordane $>$ dieldrin $>$ endrin ketone $>$ methoxychlor $>$ endrin $>$ aldrin $>$ endrin aldehyde (Figure 5). The levels of $\alpha$ endosulfan residue were lower than the metabolite endosulfan sulphate. The mean concentration of endosulfan sulphate detected in $25 \%$ of biota samples from the study area was $3.80 \mu \mathrm{gKg}^{-1}$ and ranged from $0.10 \mu \mathrm{gKg}^{-1}$ to $10.85 \mathrm{\mu g} \mathrm{gg}^{-1}$ while that of $\alpha$-endosulfan was $3.56 \mu \mathrm{gKg}^{-1}$ ranging from $0.15 \mu \mathrm{gKg}^{-1}$ to $16.5 \mu \mathrm{gKg}^{-1}$. DDE was present in the highest concentration with a mean of $7.99 \mu \mathrm{gKg}^{-1}$ and ranged from $0.10 \mu \mathrm{gKg}^{-1}$ to $30.90 \mu \mathrm{gKg}^{-1}$. DDT levels in fish samples were lower than the DDE, indicating a high degradation rate under this climatic condition (Jiries et al., 2002) which is characteristic of a typical 


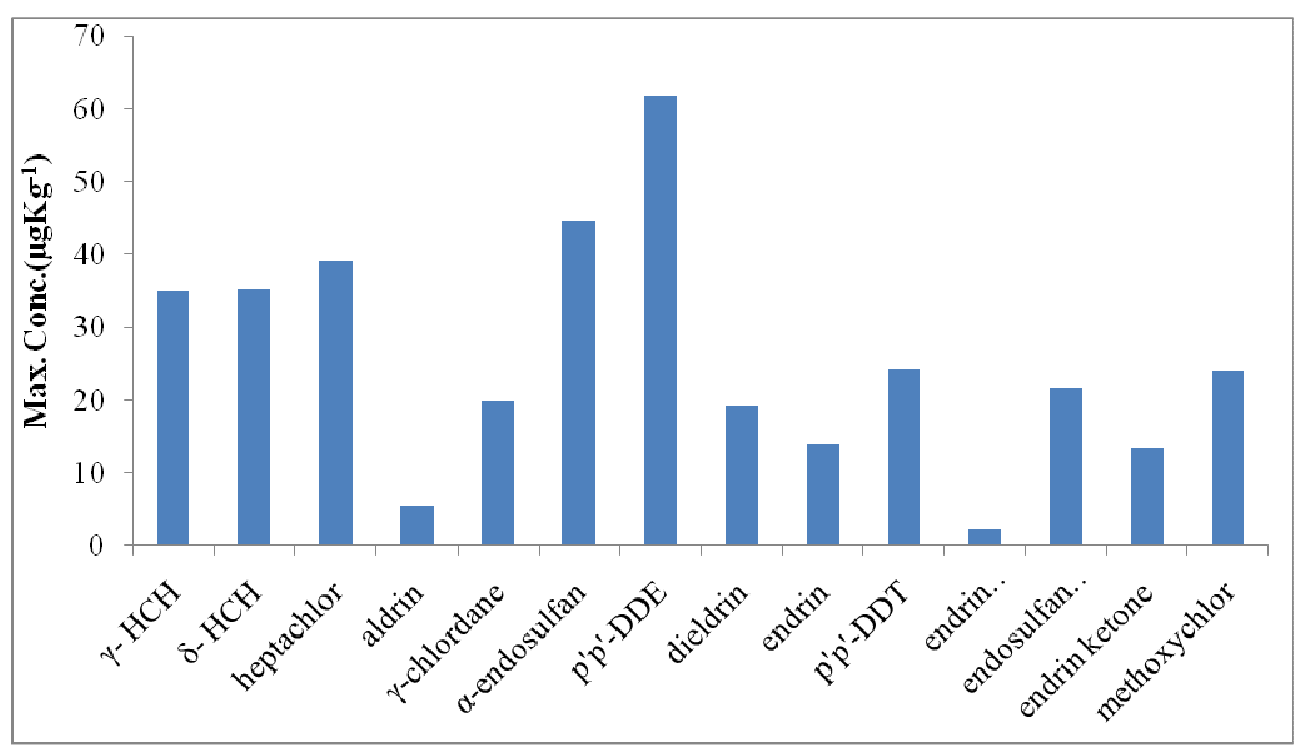

Figure 5: Maximum concentrations of pesticide residues detected in fish samples

tropical water body. The levels of DDT were between $0.1 \mu \mathrm{gKg}^{-1}$ to $12.50 \mu \mathrm{gKg}^{-1}$ with a mean of $4.01 \mu \mathrm{gKg}^{-1}$. Substantial levels of $\gamma$ $\mathrm{HCH}$ and heptachlor were registered in all fish samples. Their values fluctuated between 0.1 $\mu \mathrm{gKg}^{-1}$ and $17.65 \mu \mathrm{gKg}^{-1}$ for $\gamma-\mathrm{HCH}$, and 1.3 $\mu \mathrm{gKg}^{-1}$ to $21.50 \mu \mathrm{gKg}^{-1}$ for heptachlor.

Although the agricultural use of DDT was banned in Ghana, this insecticide and its metabolite DDE was still detected in higher levels in biota samples indicating clearly that these more potent agrochemicals are used irrespective of the ban. This demonstrates the well known persistence of these substances even in tropical environment (Kidd et al., 2001) and justifies its prohibition from agricultural use in Ghana. The DDE/DDT ratios were high in most fish samples. The ratios ranged from 0.1 to 6.90 with a mean of 2.51 indicating old input of DDT and significant degradation. Those that recorded low ratios could be recent inputs of DDT.

The higher levels of DDT, DDE and endosulfan in the study area might be due to the higher bio-accumulative properties of these compounds and large past usage. DDT and dieldrin have been used in agriculture and public health (malaria eradication) (Clarke et al., 1997) while aldrin have been used against termites with lindane and endosulfan restricted for the control of capsids on cocoa, stem borers in maize and pest on coffee. As compared to DDE, DDT, and endosulfan sulphate, the concentrations of $\mathrm{HCHs}(\gamma-\mathrm{HCH}$ and $\delta-\mathrm{HCH}$ ) were lower, because they are much less bioaccumulative with low lipophilicity and short half-life in biota (Sudaryanto et al., 2007). Above all, HCHs are easily volatalized and transported through air and water to long distances. Hence the prevailing high temperatures in Ghana would speed up the volatilization of these compounds.

Although concentrations of $\mathrm{HCHs}$ were substantial in all the sapling locations, there were differences in the isomer patterns among the locations and species. $\gamma-\mathrm{HCH}$ constituted a major proportion in total $\mathrm{HCH}$ in fish from the study area, suggesting a preferential usage of lindane (purified $\gamma-\mathrm{HCH}$ ) in these areas. The $\gamma$-HCH isomer (lindane) was the dominant $\mathrm{HCH}$ in fish samples. The low $\delta$ - 
$\mathrm{HCH} / \gamma-\mathrm{HCH}$ ratios in most fish samples indicated the present input of the pesticide lindane from non-point sources and perhaps its recent use in the nearby area. The detection of $\delta-\mathrm{HCH}$, which is the least persistent of the $\mathrm{HCH}$ isomers and thus seldom found in environmental samples, strengthens the evidence that technical $\mathrm{HCH}$ had been used recently. The concentration level of $\gamma-\mathrm{HCH}$, $\delta$ - $\mathrm{HCH}$, heptachlor, aldrin, $\gamma$-chlordane , $\alpha$ endosulfan, endosulfan Sulphate, p'p'-DDE, dieldrin , endrin p'p'-DDT, endrin aldehyde, endrin ketone and methoxychlor found in fish samples were below the extraneous residue limit of $200 \mu \mathrm{g} / \mathrm{kg}$ fresh weight in fish and seafood set by the Codex Alimentarious Commission of FAO/WHO (1997).

\section{Suitability of biota for human consumption}

The mean values and ranges of total DDT found in biota from the Densu Basin were significantly below the FAO/WHO maximum acceptable limits in fish and sea food (200 $\mu \mathrm{g} \mathrm{kg}^{-1}$ fresh weight) and Canadian maximum allowable limit in fish $\left(500 \mu \mathrm{g} \mathrm{kg}^{-1}\right.$ fresh weight). The acceptable daily intake (ADI) of total endosulfan is given as $6.00 \mu \mathrm{g} \mathrm{kg}^{-1}$ body weight (FAO/WHO 2002). This means that; for an average adult of $60 \mathrm{~kg}$ body weight, a daily intake of $0.36 \mathrm{mg}$ of pesticide per day is tolerable. The maximum level detected in the study was $16.50 \mu \mathrm{gKg}^{-1}$ fresh weights. Although residue levels of these pesticides are below the maximum permissible intake of Codex Committee on pesticides residues (FAO/WHO, 2007), consumption of fish and fisheries products from the basin was no zero risk because there were pesticides present in fish. Most of the detected compounds are generally persistent, volatile, lipophilic and bioaccumulative both in the environment and at each trophic level of the food chain. Contaminants can thus reach high concentrations through biomagnifications in the tissues of predators including humans, which are high on the food chain (Botchway, 2000). They are prone to long range transport and deposition and can result in adverse environmental and human health effects at locations near and far from the source.

\section{Conclusion}

The Densu River Basin in Ghana has a special economic significance, representing the country's greatest hydro-structure but bedeviled with multiple anthropogenic influences that impact negatively on its resources. The results indicate that all the detected residues and metabolites in fish samples from the Densu River Basin were organochlorines (OCs). The total concentration of pesticide residues detected in the fish samples ranged from $0.49 \mu \mathrm{gKg}^{-1}$ to $8.90 \mu \mathrm{gKg}^{-1}$ with the highest level detected in Hepsetuss odoe (HO-N). However, higher proportions of pesticide residues were detected in fish from the rural areas at Nsawam and its environs (HN-N, CO-N, HO$\mathrm{N}$, TZ-N and CG-N) than those from other sampling sites in the basin. The presence of pesticide residues in fish is of concern because fish is the main protein diet for many people in the basin. Most of the detected compounds are generally persistent, lipophilic and bioaccumulative both in the environment and at each trophic level of the food chain. Although most of the residues detected were banned for agricultural use in Ghana and were well below the allowable maximum limits, they were detected in fish samples which demonstrated the environmental persistence of these substances and their ability to bioaccumulate in biological tissues; hence they might still pose a potential risk for public health.

\section{REFERENCES}

Aboagye E. 2002. Patterns of pesticide use and residue levels in exportable pineapple (Ananas cosmosus L. Merr). 
M.Phil Thesis, University of Ghana, Legon, Ghana.

Adeyemi D, Ukpo G, Anyakora C , Unyimadu JP. 2008. Organochlorine pesticide residues in fish samples from Lagos Lagoon, Nigeria. Am. J. Environ. Sci, 4(6): 649-653.

Akerblom M. 1995. Environmental Monitoring of Pesticide Residues: Guidelines for the SADC Region(series 3). SADC/ELMS, Monitoring techniques: Lesotho.

Amoah P, Drechsel P, Abaidoo RC, Ntow WJ. 2006. Pesticide and pathogen contamination of vegetables in Ghana's urban markets. Arch. Environ. Contam. Toxicol., 50(1): 1-6.

Attua EM. 2003. Land cover change impacts on the abundance and composition of flora in the Densu basin. West Afr. J. Appl. Ecol., 4: 27-34.

Botchway F. 2000. Analysis of Pesticide Residues in Ghana's Exportable Cocoa, Higher Certificate Project. Institute of Science and Technology: London.

Carvalho PF. 2006. Agriculture, pesticides, food security and food safety. Environ Sci. Policy., 9: 685-692.

Clarke EEK, Levy LS, Spurgeon A, Calvert IA. 1997. The problems associated with pesticide use by irrigation workers in Ghana. Occup. Med., 47(5): 301-308.

FAO/WHO.1997. Codex maximum residue limits for pesticides. FAO/WHO, Rome.

FAO/WHO. 2002. Report of the Thirty-Fourth Session of the Codex Committee on Pesticide Residues. Food and Agriculture Organization of the United Nations / World Health Organization. The Hague, Netherlands.

FAO/WHO. 2007. Codex maximum residue limits for pesticides. FAO/WHO, Rome.

FDA. 1994. Pesticides Analytical Manual, Multiresidue method. No. 94-1 (1/94). From 2905a (6/92). FDA.
Hill A. 2000. Quality Control Procedures for Pesticide Residues Guidelines for Residues Monitoring in the European Union $\left(2^{\text {nd }}\right.$ edn). European Commission. Document No. SANCO/3103/2000,

Jiries AB, Al Nasir FM, Beese F. 2002. Pesticide and heavy metals residue in wastewater, soil and plants in wastewater disposal site near Al-lajoun valley, Karak/Jordan. Water, Air, Soil Pollu., 133: 97-107.

Kidd KA, Bootsma HA, Hesslein RH. 2001. Biomagnification of DDT through the benthic and pelagic food webs of Lake Malawi, east Africa: Importance of trophic level and carbon source. Environ. Sci. Technol., 35: 14-20.

Liu B, Mcconnell LL, Torrents A. 2002. Herbicide and Insecticide loadings from the Susquehanna River to the Northern Chesapeake Bay. J. Agric Food Chem., 50: 4385-4392.

Mensah FO, Yeboah FA, Akman M. 2004. Survey of the effect of aerosol pesticide usage on the health of farmers in the Akomadan and Afrancho farming community. J. Gh. Sci. Assoc., (6)2: 4448.

MOFA (Ministry of Food and Agriculture). 2003. Agriculture in Ghana: Facts and Figures. Produced by the Statistics, Research and Information Directorate: Accra.

Ntow JW. 2005. Pesticide residues in Volta Lake, Ghana. Lakes and Reservoirs. Research and Management, 10: 243-248.

Sudaryanto A, Monirith I, Kajiwara N, Takahasi S, Hartono P, Muawanah Omori K, Takeoka H, Tanabe S. 2007. Levels and distribution of organochlorines in fish from Indonesia. Environment International, 33: 750-758.

Tanabe A, Kawata K. 2009. Daily variation of pesticides in surface water of a small river 
flowing through paddy field area. Bull. Environ. Contami. Toxicol., 82: 705-710.

Tariq MI, Afzal S, Hussain I, Sultana N. 2007. Pesticide Exposure in Pakistan: A Review. Environ. Int., 33: 110.

Wasswa J, Kiremire BT. 2004. Pesticide Residue distribution in sediment and fish samples from the Uganda side of Lake Victoria. ANCAP inaugural conference proceedings, Tanzania, 7-14.

WRI (Water Research Institute). 2003. Groundwater Assessment: An Element of Integrated Water Resources Management
- The case of Densu River Basin. WRI: Accra. Ghana.

WRC (Water Resources Commission). 2007. Integrated Water Resources Management Plan-Densu River Basin. WRC: Accra.

Zhou JL, Hong H, Zhang Z, Maskaoui K, Chen W. 2000. Multi-phase distribution of organic micropollutants in Xiamen Harbour, China. Water Research, 34: 2132-2150. 